\title{
PROMOTING NON-VIOLENT PARENTING AMONG REFUGEE MOTHERS IN DURBAN
}

\section{Beatrice Umubyeyi, Geoff Harris}

\section{INTRODUCTION}

Corporal punishment can be defined as an action taken by a parent, teacher or caregiver resulting in physical pain or discomfort to a child with the aim of changing the child's behaviour. Those who support the use of corporal punishment believe that it is an appropriate and effective means of deterring misbehaviour and encouraging desired behaviour.

Supporters of corporal punishment argue that there is a clear distinction between punishment to control and correct a child and physical abuse. However, corporal punishment can easily turn into abuse and some of its opponent (Coleman, Dodge \& Campbell, 2010) argue that any corporal punishment is by definition abusive. Durrant (2005:50) cautions that corporal punishment and physical abuse lie on "a continuum of violence and that is not possible to draw a line that distinguishes where punishment ends and abuse begins".

The authors' disciplinary base is conflict resolution and peace studies, and a brief explanation of relevant peace concepts is relevant. A social work perspective is provided by ChetknowYanoov (1997). The term conflict refers to differences of interest between individuals, such as a parent and a child, and groups. It is inevitable, common and is normally resolved without recourse to violence. Violence involves harming others in the pursuit of one's own interests. It may involve physical actions (including corporal punishment), but also words, attitudes, structures or systems that cause physical, psychological, social or environmental damage and thus prevent people from reaching their full human potential. There are a range of views on whether and when violence can justifiably be used. In terms of parenting, those in favour of corporal punishment believe it is an effective way of teaching respect and right behavior. Those against its use argue that it is not effective in these respects and in fact educates children to use violence. More fundamentally, they believe it violates the principles of non-violence as a way of life which emphasises such values as patience, love and forgiveness.

Conflict management focuses on preventing a conflict moving into violence, often by separating the conflicting parties in the hope that a resolution can be achieved. Non-violent conflict resolution focuses on finding solutions which both parties are willing to accept, thus "solving" the conflict and achieving a sustainable peace. Conflict resolution is based on selfawareness and effective communication, but may do little for the relationship between the parties, even though they may be satisfied with the outcome. Conflict transformation tries to restore a good relationship or to build one, if it did not previously exist. A major assumption in peace studies is that peace and non-violence can be learned and violence unlearned. Parents can learn to bring up their children using non-violent methods and children can learn to interact non-violently with others.

The aims of this study are to determine the attitudes and behaviour of a sample of refugee mothers concerning the use of corporal punishment and then to design and implement a nonviolent parenting training course with a sample of these mothers. There will also be a very preliminary assessment of the effects of the training on the mothers' attitudes towards disciplining their children. 


\section{CORPORAL PUNISHMENT: EXTENT, CAUSES AND CONSEQUENCES}

The use of corporal punishment is widespread worldwide. Recent studies (Corrine, Michelle, Jennifer \& Mikulka, 2008, Hicks-Pass, 2009; Mulvaney \& Mabert, 2010; Straus, 2010) estimate that as many as 90 per cent of parents in countries such as the US, the UK and New Zealand use corporal punishment, although support for its use is declining over time (Dawes, De Sass Kropiwnicki, Kafaar \& Richter, 2004:32). Such high rates contrast with its minimal use in Sweden, which banned all forms of corporal punishment in 1979 and embarked on efforts to promote non-violent disciplinary alternatives (Durrant, 2003).

Durrant (2005) provides compelling evidence that children who have been subject to corporal punishment are very likely, when they become adults, to approve of it and to use it in the upbringing of their own children. In addition to holding attitudes which support its use, a number of non-personal factors may encourage the use of corporal punishment. These are summarised in Table 1. More broadly, Grogan-Kaylor and Otis (2007) have examined the predictors of parental use of corporal punishment in the US context.

TABLE 1

FACTORS ASSOCIATED WITH THE USE AND/OR APPROVAL OF CORPORAL PUNISHMENT

\begin{tabular}{|c|c|c|}
\hline Factor & Suggested influence & Reference(s) \\
\hline $\begin{array}{l}\text { Cultural attitudes and } \\
\text { religious beliefs }\end{array}$ & $\begin{array}{l}\text { Conservative beliefs are associated with } \\
\text { greater use and/or approval }\end{array}$ & $\begin{array}{l}\text { Dawes et al. }(2004) \\
\text { Firmin \& Castle (2008) }\end{array}$ \\
\hline Ethnicity & $\begin{array}{l}\text { Different ethnic groups have different } \\
\text { levels of use and/or approval }\end{array}$ & $\begin{array}{l}\text { Dawes et al. (2004) } \\
\text { Buldukoglu \& Kukulu (2008) }\end{array}$ \\
\hline Education & $\begin{array}{l}\text { Lesser educated parents are more likely } \\
\text { to use and/or approve }\end{array}$ & $\begin{array}{l}\text { Chamberland \& Clement } \\
\text { (2009) } \\
\text { Straus (2010) }\end{array}$ \\
\hline Economic status & $\begin{array}{l}\text { Low-income households are more likely } \\
\text { to use and/or approve }\end{array}$ & Gershoff (2002) \\
\hline $\begin{array}{l}\text { Level of violence } \\
\text { between parents }\end{array}$ & $\begin{array}{l}\text { More violent parental relationships are } \\
\text { likely to result in use and/or approval }\end{array}$ & $\begin{array}{l}\text { Corrine et al. (2008) } \\
\text { Dawes } \text { et al. (2004) }\end{array}$ \\
\hline Number of children & $\begin{array}{l}\text { Parents with larger families are more } \\
\text { likely to use and/or approve }\end{array}$ & $\begin{array}{l}\text { Chamberland \& Clement } \\
\text { (2009) } \\
\text { Straus (2010) }\end{array}$ \\
\hline Gender aspect 1 & $\begin{array}{l}\text { Boys are more likely to receive corporal } \\
\text { punishment than girls }\end{array}$ & $\begin{array}{l}\text { Firmin \& Castle (2008) } \\
\text { Devaney (2008) }\end{array}$ \\
\hline Gender aspect 2 & $\begin{array}{l}\text { Mothers use corporal punishment more } \\
\text { frequently and fathers use it more } \\
\text { intensely }\end{array}$ & $\begin{array}{l}\text { Dawes et al. (2004) } \\
\text { Humphreys (2008) }\end{array}$ \\
\hline
\end{tabular}

Turning to the consequences of corporal punishment, the findings of academic studies on the effects of corporal punishment was the subject of a meta-analysis of 88 academic studies by Gershoff (2002). A summary of these results by Durrant (2005) is presented in Table 2. In short, the studies show overwhelming evidence of the negative effects of corporal punishment on child health, their behaviour as children and later as adults, and on the relationship between 
parents and children. The only positive outcome detected was immediate compliance by the child after corporal punishment or its threatened use.

TABLE 2

DEVELOPMENTAL OUTCOMES ASSOCIATED WITH CORPORAL PUNISHMENT

\begin{tabular}{|l|c|c|}
\hline \multicolumn{1}{|c|}{ Outcome } & $\begin{array}{c}\text { Number of studies } \\
\text { examining relationship }\end{array}$ & $\begin{array}{c}\text { Number of studies } \\
\text { confirming relationship }\end{array}$ \\
\hline Child victim of physical abuse & 10 & 10 \\
Poorer child mental health & 12 & 12 \\
Poorer adult mental health & 8 & 8 \\
Impaired parent-child relationship & 13 & 13 \\
Lower moral internalisation & 15 & 13 \\
Child aggression & 27 & 27 \\
Adult aggression & 4 & 4 \\
Child delinquent and antisocial behaviour & 13 & 12 \\
Adult antisocial behaviour & 5 & 5 \\
Abuse of child or spouse in adulthood & 5 & 5 \\
\hline
\end{tabular}

Source: Durrant (2005:73)

The effects of corporal punishment will also be felt at the macro level. In his book Parenting for a peaceful world Robin Grille provides persuasive evidence that "the collective childhood experience of a society is probably the single most important factor driving group decisions made at political, business and social levels" (2005:100). In the early 1900s, for example, the German model of child-rearing emphasised rigorous obedience training and minimal demonstrations of affection from infancy onwards. Grille argues that it was "this kind of childhood atmosphere ... taken to extremes, [that] gave rise to the hatred, the lack of compassion and the blind obedience that comprised the engine of the Nazi phenomenon" (Grille, 2005:120). In case this is objected to as an extreme example, Grille also provides data from major studies of parenting styles in rural Yugoslavia during the 1930s, in Russia in the late $19^{\text {th }}$ century, in various religious groups and in $20^{\text {th }}$ century democracies such as France, the US and Sweden (Grille, 2005:99-174).

\section{CORPORAL PUNISHMENT IN SOUTH AFRICA}

While there have been a number of studies on corporal punishment in South African schools many following its banning in 2006 - there are relatively few which have examined corporal punishment by parents. There is, fortunately, one major study - Partner violence, attitudes to child discipline and use of corporal punishment: a South African national survey (Dawes et al., 2004) - data collection for which was carried out under the South African Social Attitude Survey. From this nationally representative survey a sub-sample of 952 parents with children (31 per cent of whom were men and 69 per cent women) were surveyed in late 2003 with respect to their attitudes towards discipline and the use corporal punishment.

The major finding was that 57 per cent of parents with children under 18 reported having smacked their children at some time, with 33 per cent using severe corporal punishment, that is, 
using a belt or stick as opposed to smacking. The most common age of children subject to smacking was three years; for those subject to severe corporal punishment, the figure was four years.

There were gender, age and ethnic variations. Of those parents who reported using mild corporal punishment (i.e. smacking) on their children in the last year, 70 per cent were women; parents younger than 35 were less likely to use corporal punishment; and Africans and whites were more likely to use mild and severe corporal punishment than coloured or Indian parents.

In summary, the incidence of corporal punishment in South Africa was extensive, while certainly lower than the rates reported earlier. More significantly, a high proportion was severe corporal punishment and was practised on very young children. These data say nothing about the use of corporal punishment within the refugee community, but the high levels of stress experienced by refugees, and particularly refugee mothers (Holscher, Sathiparsad \& Mujawamariya, 2012), suggest that its incidence may well be at least as high as among South Africans.

\section{ALTERNATIVES TO CORPORAL PUNISHMENT}

It is possible for parents who use corporal punishment to learn non-violent alternatives. A number of recent studies (Barth, 2009; Grille, 2005; Latini, 2009; Wiggins, Sofronoff \& Sanders, 2009) have argued that the practice of non-violent parenting can reduce misbehaviour and equip children with self-confidence and responsibility. Various non-violent parenting programmes are offered in countries such as the US, the UK and Australia, including the Positive Parenting Curriculum Package, The Incredible Years Parenting Training Programme and Parenting the Strong-Willed Child. These typically emphasise communication between parents and children, spending quality time together and training children for the tasks they are expected to undertake and aim to build parent-child relationships, positive behaviour and selfdiscipline in children. Evaluations of such programmes (Berard \& Smith, 2008; Letarte, Normandeau \& Allard, 2010; Marcynyszyn, Maher \& Corwin, 2010) have typically used preand post-training questionnaires and found high levels of approval among participants. Many parents, it seems, have quite limited knowledge and skills in the area of conflict management and resolution as these apply to children.

\section{THE RESEARCH PROJECT}

The overall objective of the research was to promote the use of non-violent parenting methods among refugee mothers in Durban. Its specific aims were:

- To determine the attitudes and behaviour as regards parenting and discipline of a sample of mothers from the Durban refugee community;

- To design and implement a non-violent parenting training course with a sample of refugee mothers;

- To carry out a very preliminary assessment of its effects on the attitudes of the mothers towards disciplining their children.

Accordingly, three stages of the research were planned:

- An initial questionnaire completed by 50 respondents and two focus groups with 8 participants in each. These were designed to meet specific aim 1;

- Designing a training manual and training the two groups of eight in non-violent parenting (in one three hour session each) to meet specific aim 2; 
- An evaluation session of one hour to meet specific aim 3.

Convenience sampling was used to select 50 mothers from Emmanuel Cathedral (Catholic) and Durban Mission churches with one or more children aged between two and 10 years. The questionnaire was printed in English and Swahili, and focused on their attitudes towards corporal punishment and the frequency and intensity with which they use it. The survey took place in June 2011. From the initial sample, 16 volunteers (eight from each church) were sought to participate in the focus groups (in July 2011), training (in September 2011) and evaluation (in October 2011). Copies of the questionnaire, focus group questions, the training manual and the evaluation questions are available on request. Ethical clearance was granted by the Ethics Committee of the University of KwaZulu-Natal and its strict guidelines were followed throughout the project.

\section{FINDINGS ON CHILD DISCIPLINE PRACTICES}

\section{DATA FROM THE INITIAL QUESTIONNAIRE}

The initial group of 50 mothers originated from the Democratic Republic of Congo (35), Zimbabwe (10) and Burundi (5); almost all had been in South Africa for less than five years and 21 for less than two years. They had an average of 2.4 children with an average age of 5.1 years and found life very stressful, mainly as a result economic hardship and their living conditions.

The 50 mothers varied widely concerning their use of discipline methods and used different methods according to the circumstances. Sixteen used beating and another nine used yelling as their most common method, while 23 used talking and 10 used "other" methods. Fifteen respondents said that they used corporal punishment every day or most days and another 10 once a week; eight mothers said that they never used it. As to whether corporal punishment was necessary in bringing up children, 19 said yes (of whom nine felt this very strongly), 19 had mixed feelings and 12 said it was not necessary (five very strongly).

Forty respondents indicated that corporal punishment had important positive outcomes in terms of teaching children discipline, good behaviour and respect. In the words of one respondent:

"Corporal punishment is important in bringing up responsible children. If you do not discipline your children at the early age, you are not doing any good the future society. Children must be disciplined, so we can have a society where there is respect."

Respondents had varying views on the negative consequences of corporal punishment respondents, but a number suggested that children subjected to corporal punishment might develop a sense of mistrust and sometimes hatred towards their parents. There was also a sense that children might behave well out of a fear of corporal punishment, but then behave badly when their parents were not around.

An open-ended question asked the respondents for the most important reason that parents (not necessarily themselves) used corporal punishment. Twenty said that the Bible teaches it, 15 that children need to be controlled or they will "take over" and 10 because it promotes good behaviour.

\section{DATA FROM FOCUS GROUP DISCUSSIONS}

The two focus groups comprised eight members each, drawn from volunteers who completed the questionnaire, and were held to explore attitudes and behaviour concerning the discipline of 
children in more detail. Each group lasted about 90 minutes. The respondents' own words are used as much as possible to report typical responses, with alternative views noted. Four questions were devised following analysis of the initial questionnaire responses and the researchers, in accordance with the principles of focus group methodology, played only a facilitating role in the actual discussion.

\section{Question 1 - What methods do you use to discipline your children and why do you use them?}

Most participants agreed that the use of corporal punishment can deter children from misbehaving, can teach them to be respectful and to grow up to be responsible adults, and it was often suggested as proof that the parent loved the child.

"I think that there is no better way of disciplining a child than to use corporal punishment. As you know, many of the children are difficult and just to say 'Do not do this' does not work. Children won't listen. The only thing to make your child understand in some instances is to beat them."

"We punish our children because we care about them."

In contrast, a minority of participants supported the idea of communication as the best means of correcting a child.

"Communication can assist children getting the message better than beating them. Sometimes you will find parents who just beat their children without even telling them why they are beating them. How do you expect a child to behave well while the child cannot know what his/she has done wrong?"

A minority of the mothers argued that under no circumstances the child should be subjected to corporal punishment. They believed that corporal punishment is violence against a child and therefore cannot be tolerated.

"It is very bad to hit a child any time he misbehaves. Everybody makes mistakes. So if we say that everyone who make mistakes or does something wrong, must be [physically] punished, it is not good. All people, even children, must be given opportunity to correct themselves through advice."

While corporal punishment and communication emerged as the major methods used in disciplining children, some other methods were also used. These included holding back some privileges from a child, for example, forbidding the child from playing with other children or watching TV.

\section{Question 2 - Do you think the Bible encourages you to use corporal punishment on your children?}

Many participants argued that corporal punishment is strongly recommended and even commanded in the Bible. The relevant verses are Proverbs 22:15: "Folly is bound up in the heart of a child, but the rod of discipline will drive it far from him". Proverbs 23:13-14: "Do not withhold discipline from a child; if you punish him with the rod, he will not die. Punish him with the rod and save his soul from death". Proverbs 13:24: "He who spares the rod hates his son, but he who loves him is careful to discipline him or punish him".

For some participants - and this was particularly true in the Durban Mission focus group - that was the end of the discussion. This accords with the findings of Dawes et al. (2004) and Firmin 
and Castle (2008) of a positive relationship between religious conservatism and the use of corporal punishment.

"Those parents who do not discipline their children have not used their responsibility according to what God has given them. In my view, all parents should punish their children, not for the sake of hurting them, but to help them grow up as good and responsible persons."

Others, however, indicated that it is still up to the parents to make the choice to use it or not:

"I do not mind to whether someone disciplines his/her child. What matters for me is that my children are disciplined and grow up with respect. Some of the parents prefer to use corporal punishment and others not. What works for them, they should apply that."

In contrast to the above views, a few of the mothers argued that whether the Bible encourages the use of corporal punishment on children or not, they did not believe it is an effective way of disciplining children; some of this minority reject corporal punishment because it is violent.

\section{Question 3 - Can you think of any negative aspects of using corporal punishment?}

Most participants agreed that the use of corporal punishment has negative aspects, but that it all depends on how corporal punishment is administered, particularly the intensity and frequency of its use; this accords with the views reported by Chamberland and Clement (2009). All respondents agreed that if corporal punishment is over-used, it can have harmful consequences. The common reasoning, incidentally, was not because of its negative impact on the child, but because it can lead to a situation where the child will no longer care about punishment and therefore will no longer obey parents' instructions. Longer-term impacts were also identified:

"Children who are subjected to physical punishment tend to be more aggressive than the children who are not. You see that children who are subject to it are likely to grow up using violence on other children at home and even at schools."

"In my view, too much beating has serious consequences. Some children keep what their parents do to them in their memory and when they grow up, they treat their own children in the same way. Also sometimes ... when they become adults they end up beating their parents."

\section{Question 4 - Do you know of alternative methods of disciplining children other than using corporal punishment?}

Even those participants who supported the use of corporal punishment were able to suggest alternatives to it. Communication was by far the most important of these alternatives:

"Communication builds the society, not only for the adult but also for the children. Imagine a family or a society where there is no communication between parents and children, or a family where there is no communication between parents."

"For me, I use communication to educate my children. Punishment only comes when I see that the child repeats the mistakes I already discussed with him/her. We all need to be told in a nice way, not always to be brutalised."

The researchers probed to find out why, if participants saw communication as effective, they continued to use corporal punishment. Respondents indicated that corporal punishment is a quick way of punishing a child and some admitted that they used corporal punishment out of 
anger and frustration, supporting the idea that high stress levels among refugee mothers may result in more corporal punishment (Chamberland \& Clement, 2009; Holscher et al., 2012).

"Sometimes, it is out of anger we beat our children. Sometimes you tell a child and the child does not understand. You come home tired and with other many other things in your life and when children start misbehaving then you lose your mind."

Some mothers indicated that after hitting their children, they often regretted their actions. Some indicated that they ask their children to forgive them after using corporal punishment.

\section{TRAINING IN NON-VIOLENT ALTERNATIVES}

The training course was devised after analysing the survey and focus group responses. Each group comprised the same members as the focus groups and lasted for around three hours. Each was based on participatory learning methods and group discussion using the training manual and comprised five sections:

1. Understanding corporal punishment;

2. The Bible and corporal punishment;

3. The negative consequences of corporal punishment;

4. Building good parent-child relationships;

5. Some non-violent discipline techniques.

Section 1 examined the view that corporal punishment is part of a continuum of violence (Coleman et al., 2010; Durrant, 2005) and that it is difficult to draw a line that marks where punishment ends and abuse begins. Role plays - with participants taking the roles of parents and children - were used to give a window into the way both groups feel about corporal punishment.

In section 2 participants considered in small groups whether the Bible verses mentioned earlier were a good foundation on which to base child discipline practice. New Testament passages about how we are meant to relate to other people, including our children, were discussed. During plenary sessions it emerged that participants had come to agree that the Bible does not teach or promote the use of corporal punishment.

"Sometimes people turn the Bible up and down. You know even in Congo, some people used the Bible to kill other people... This question of corporal punishment and the Bible is somehow misused by some of the church leaders."

Section 3 considered the consequences of corporal punishment and many expressed surprise that any lasting negative effects could occur; that said, they did not argue against this evidence. A representative comment (from a non-user of corporal punishment) was:

"Old people say that the stick can break the bone, but can never break the behaviour. We can beat our children as much as we want. But if you do not use appropriate methods [of discipline], our children will never listen to us. The use of corporal punishment on children can affect our relations with them ... we are creating enemies with those whom we want as our best friends."

In section 4 participants were asked to suggest ways of building good relationships between parents and children. Four methods were suggested which, it might be noted, were quite similar to those discussed by Power and Hart (2005): 
- Show them the sort of behaviour you want from them by modelling it in your life;

- Show them that you love them by spending quality time with them and by hugging them a lot;

- Listen carefully in order to understand children what they need;

- Negotiate with them.

The final section involved the participants proposing some non-violent discipline techniques they could use. A number of non-violent discipline methods were suggested and discussed by participants, again similar to many of the suggestions in Power and Hart (2005).

\section{A VERY PRELIMINARY EVALUATION}

One month after the training, all but one of the participants came together to discuss two questions:

- In what ways (if any) did the training change your ideas about corporal punishment?

- In what ways do you intend to behave different as a result?

During the evaluation process, all of the participants agreed that the training workshop had led to important changes in their views about corporal punishment. They agreed that if non-violent alternatives were properly applied, it would assist in building good relationships between parents and children, which they saw as a central objective in parenting. This, it seems, was the main lesson from the training.

Some typical statements are as follows:

"I did not think that beating your own child was a problem and has an impact on the child. I usually thought that corporal punishment is the only way we can as parents make children do things that we want, but after [the training], I went home and discussed with my husband. I discovered that corporal punishment is violence."

"For me, I never previously beat my children when one misbehaves. I just talk to him and explain. The workshop has helped me to do this better."

"You see, I have children who do not understand, especially the boy child. You cannot tell him to do this and do that [because] he just does something else. From the day of the training, I started applying some of the skills presented. Maybe it will work."

As to the second question, all participants said that they intended to behave differently. When asked what they meant by this, most of them indicated that they wanted to learn to communicate with their children. They were concerned to build good relationships with their children, which would then allow them to have dialogue with their children about behavioural issues when the need arose, and thus do away with the need to use of corporal punishment.

Three issues concerning the reliability of these results need to be considered. First, there may be selection bias in that those who volunteered for the training may have been predisposed towards non-violent parenting. However, there was a wide range of opinions among those who completed the initial questionnaire and also among those who volunteered to participate in the focus groups and training. Second, it may be that the evaluation responses were what the respondents believed the researchers and the other participants wanted to hear. Our strong impression, however, is that these responses were genuine and that their eyes had been opened to alternative ways of parenting, which they became keen to adopt. Many had been unhappy using corporal punishment, and especially when they did so in anger, but did not see any alternative. Third, the evaluation can only be described as very preliminary; the real impact of 
the training will only be felt in the weeks, months and years ahead. Changes in attitude are an important determinant of behaviour, but various environmental factors such as stress levels, the relationship of the parents and the expectations of peers also influence actual behaviour.

\section{CONCLUSION}

This article has reported an intervention to build skills in non-violent parenting among a small sample of refugee mothers in Durban. There was an apparent shift towards non-violent methods of disciplining children following the training, at least as expressed verbally by the participants.

If the research of Grille and others is accepted, one way of building a more peaceful society is to bring up children using non-violent methods of discipline. This small-scale study found that mothers can be educated in such alternatives and were very open to adopting them. It seems that, deep down, they did not want to use corporal punishment, but lacked the knowledge of alternatives and were fearful that non-violent methods would not work.

One way of spreading this message is by offering such workshops to church-based groups of mothers. Given the very high levels of church affiliation and attendance in South Africa, and an ethos which at its best promotes gentleness, patience and non-violence, churches are the ideal institution through which to promote non-violent parenting.

\section{REFERENCES}

BARTH, R. 2009. Preventing child abuse and neglect with parent training: evidence and opportunities. Future of Children, 19(2):95-112.

BERARD, K.P. \& SMITH, R.G. 2008. Evaluating a Positive Parenting Curriculum Package: an analysis of the acquisition of key skills. Research on Social Work Practice, 18(5):442-452.

BULDUKOGLU, K. \& KUKULU, K. 2008. Maternal punishment practices in a rural area of Turkey. Child Care, Health \& Development, 34(2):180-184.

CHAMBERLAND, C. \& CLEMENT, E. 2009. The role of parental stress, mother's childhood abuse and perceived consequences of violence in predicting attitudes and attribution in favor of corporal punishment. Journal Family Studies, 18:163-171.

CHETKNOW-YANOOV, B. 1997. Social work approaches to analyzing conflict. New York: The Haworth Press.

COLEMAN, D.L., DODGE, K.A. \& CAMPBELL, S.K. 2010. Where and how to draw the line between reasonable corporal punishment and abuse. Law \& Contemporary Problems, 73(2):107-165.

CORRINE, L., MICHELLE, K., JENNIFER, M. \& MIKULKA, P. 2008. Parental use of physical punishment as related to family environment, psychological well-being and personality in undergraduates. Journal of Family Violence, 23(1):1-7.

DAWES, A., DE SASS KROPIWNICKI, Z., KAFAAR, Z. \& RICHTER, L. 2004. Corporal punishment of children: a South African National Survey. Pretoria: Human Sciences Research Council.

DEVANEY, J. 2008. Chronic child abuse and domestic violence: children and families with long-term and complex needs. Child \& Family Social Work, 13(4):443-453.

DURRANT, J. 2003. Legal reform and attitudes toward physical punishment in Sweden. International Journal of Children's Rights, 11(2):147-173. 
DURRANT, J. 2005. Corporal punishment: prevalence, predictors and implications for children behaviour and development. In: Eliminating corporal punishment: the way forward to constructive child discipline. Paris: United Nations Educational, Scientific and Cultural Organization, 49-89.

FIRMIN, M.W. \& CASTLE, S.L. 2008. Early childhood discipline: a review of the literature. Journal of Research on Christian Education, 17(1):107-129.

GERSHOFF, E.T. 2002. Corporal punishment by parents and associated child behaviors and experiences: a meta-analytic and theoretical review. Psychological Bulletin, 128(4):539-579.

GRILLE, R. 2005. Parenting for a peaceful world. Richmond, Australia: The Children's Project.

GROGAN-KAYLOR, A. \& OTIS, M. 2007. The predictors of parental use of corporal punishment. Family Relations, 56(1):80-91.

HICKS-PASS, S. 2009. Corporal punishment in America today: spare the rod, spoil the child? A systematic review of the literature. Best Practices in Mental Health, 5(2):71-88.

HOLSCHER, D., SATHIPARSAD, R. \& MUJAWAMARIYA, C. 2012. Interpreting refugee women's life stories: towards a human capabilities framework for social work with cross-border migrants. The Social Work Practitioner-Researcher, 24(1):48-65.

HUMPHREYS, S. 2008. Gendering corporal punishment: beyond the discourse of human rights. Gender \& Education, 20(5):527-540.

LATINI, T.F. 2009. Nonviolent communication: a humanizing ecclesial and educational practice. Journal of Education \& Christian Belief, 13(1):19-31.

LETARTE, M.J., NORMANDEAU, S. \& ALLARD, J. 2010. Effectiveness of a parent training programme "Incredible Years" in a child protection service. Child Abuse \& Neglect, 34:253261.

MARCYNYSZYN, L.A., MAHER, E.J. \& CORWIN, T.W. 2010. Getting with the (evidencebased) programme: an evaluation of the Incredible Years Parenting Training Programme in child welfare. Children and Youth Services Review, 33(5):747-757.

MULVANEY, M. \& MEBERT, C. 2010. Stress appraisal and attitudes towards corporal punishment as intervening processes between corporal punishment and subsequent mental health. Journal of Family Violence, 25(4):401-412.

POWER, F. \& HART, S. 2005. The way forward to constructive child discipline. In: Eliminating corporal punishment: the way forward to constructive child discipline. Paris: United Nations Educational, Scientific and Cultural Organization, 91-128.

STRAUS, M.A. 2010. Prevalence, societal causes and trends in corporal punishment by parents in world perspective. Law \& Contemporary Problems, 73(2):1-30.

WIGGINS, T.L., SOFRONOFF, K. \& SANDERS, M.L. 2009. Pathways Triple P-Positive Parenting Programme: effects on parent-child relationships and child behaviour problems. Family Process, 48(4):517-530.

Ms Beatrice Umubyeyi, Research Assistant; Prof Geoff Harris, Department of Public Management \& Economics, Durban University of Technology, Durban, South Africa. 